\title{
Estimating the prevalence of obstetric fistula: a systematic review and meta-analysis
}

\author{
A J Adler , C Ronsmans, C Calvert and V Filippi
}

\begin{abstract}
Background: Obstetric fistula is a severe condition which has devastating consequences for a woman's life. The estimation of the burden of fistula at the population level has been impaired by the rarity of diagnosis and the lack of rigorous studies. This study was conducted to determine the prevalence and incidence of fistula in low and middle income countries.

Methods: Six databases were searched, involving two separate searches: one on fistula specifically and one on broader maternal and reproductive morbidities. Studies including estimates of incidence and prevalence of fistula at the population level were included. We conducted meta-analyses of prevalence of fistula among women of reproductive age and the incidence of fistula among recently pregnant women.

Results: Nineteen studies were included in this review. The pooled prevalence in population-based studies was $0.29(95 \% \mathrm{Cl} 0.00,1.07)$ fistula per 1000 women of reproductive age in all regions. Separated by region we found $1.57(95 \% \mathrm{Cl} 1.16,2.06)$ in sub Saharan Africa and South Asia, 1.60 (95\% Cl 1.16, 2.10) per 1000 women of reproductive age in sub Saharan Africa and 1.20 (95\% Cl 0.10, 3.54) per 1000 in South Asia. The pooled incidence was 0.09 (95\% $\mathrm{Cl} 0.01,0.25)$ per 1000 recently pregnant women.

Conclusions: Our study is the most comprehensive study of the burden of fistula to date. Our findings suggest that the prevalence of fistula is lower than previously reported. The low burden of fistula should not detract from their public health importance, however, given the preventability of the condition, and the devastating consequences of fistula.
\end{abstract}

Keywords: Vesicovaginal fistula, Maternal morbidity, Systematic review

\section{Background}

The World Health Organisation defines an obstetric fistula (referred to as fistula in the text below) as an "abnormal opening between a woman's vagina and bladder and/or rectum through which her urine and/or faeces continually leak [1]". Classifications of fistula vary, but they generally include fistulae from obstetric causes including vesicovaginal fistula (VVF) and rectovaginal fistula (RVF). Fistulae have devastating consequences [2,3], particularly in low income countries where women have less geographical and financial access to appropriate surgical care for repair. In high income countries they are also devastating, but they are very rare and surgery to repair them occurs more rapidly.

\footnotetext{
* Correspondence: alma.adler@lshtm.ac.uk

London School of Hygiene \& Tropical Medicine, Keppel St, London, WC1E 7HT, UK
}

In high income countries, fistulae are due to iatrogenic causes; generally the result of radiation therapy and surgical interventions [4]. In low income countries where access to intrapartum care may be restricted, fistulae are associated with a prolonged or obstructed labour, most commonly occurring when a baby's head becomes lodged in the mother's pelvis cutting off blood flow to the surrounding tissues. Prolonged obstruction can cause the tissues to necrotise leading to fistula formation [2].

Women with fistulae often experience horrific or difficult associated conditions which stem either from the fistulae itself or from the prolonged or obstructed labour which caused it [3]. The most obvious consequences are incontinence, either urinary [3], faecal or both. The constant leakage of urine and faeces can also lead to damage to the vulva and thighs [2]. Fistulae are linked with social ostracisation [5] and marginalisation [6]. Many case 
series show high rates of divorce or separation $[7,8]$, absence of sexual intercourse [6,7], loss of fertility and amenorrhea $[9,10]$ and depression $[8,11]$ among women who have a fistula.

Fistulae are thought to have the highest prevalence where maternal mortality is high, but there is great uncertainty about the actual prevalence [2]. In the 2000 Global Burden of Disease, Dolea and AbouZhar estimated that $0.08 \%$ of all births and $2.15 \%$ of "neglected obstructed labour births" resulted in fistula [12]. These estimates came from four studies only, all of which were in sub-Saharan Africa and two were hospital-based. In 2006, the WHO estimated that more than 2 million young women throughout the world live with untreated fistula, and that between 50,000 and 100,000 new women are affected each year [1]. These statistics originated from countries' rapid needs assessments and physician's reports, mostly available in the grey literature, and not from epidemiological studies using robust design, and almost none include a denominator.

In 2007, Stanton and colleagues wrote a paper [13] on the challenges of quantifying fistula. They described three types of publications reporting on frequency, incidence or prevalence of fistula. The first category of papers relied on secondary and tertiary citations (many of which culminated in personal communications) and reported the number of patients treated without denominators. The second type of publications relied on declarations made by the authors themselves, or on "surgeons' estimates" but the source of data was unclear. The third type of studies described methods and provided appropriate denominators, but with varying degrees of transparency. Stanton and colleagues were only able to find four papers in this third category [13]

The aim of our review is to provide improved estimates of the prevalence and incidence of fistula by broadening the search and including studies that may previously have been overlooked. Unlike previous reviews of fistula [12-14], we include studies that examine a broad spectrum of reproductive morbidity (including morbidity studies where fistula is but one of many outcomes studied) and/or where no cases of fistula were reported.

\section{Methods}

A two-stage systematic review was conducted in accordance with the STROBE guidelines (http://www.strobestatement.org/) using free-text and subject headings in Pubmed, Embase, Popline, Lilacs, WHO's Eastern Mediterranean database, and African Index Medicus published until the end of 2012. The first stage targeted studies specifically reporting on fistula in the title, abstract or subject headings, including search terms such as fistula, vesicovaginal fistula, and VVF. The second stage aimed at identifying additional studies that examined postpartum and reproductive morbidity more broadly, whether or not fistula was specifically mentioned as a pathology. This search

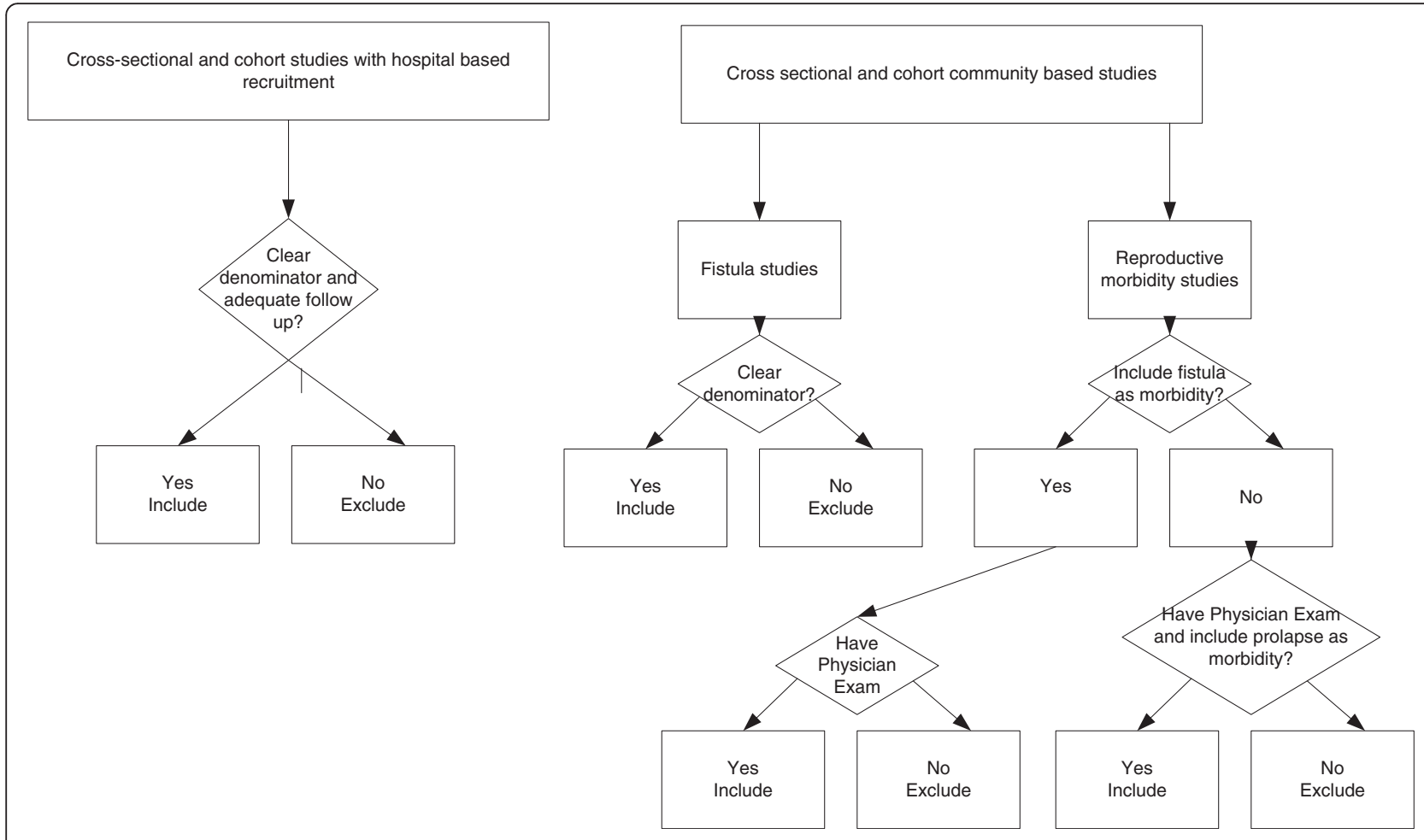

Figure 1 Types of studies included in our analysis. 
included terms such as reproductive morbidity and maternal morbidity. A full search strategy is available upon request. Only English terms were used in the search, but articles were not excluded based on language.

Reference lists were searched for additional articles. Using Web of Science, all relevant articles were subjected to forward citation searching to obtain further articles.

As illustrated in Figure 1, the following study designs were included: (i) cross-sectional or cohort studies of fistula with hospital based recruitment of pregnant or recently delivered women where the women were followed for and examined at least 30 days after the end of pregnancy and there was a clear denominator; (ii) cross sectional or cohort studies of prevalent or incident cases of fistula in the community and (iii) cross sectional or cohort studies of prevalent or incident cases of reproductive morbidity in the community. Studies were only included if women were examined for the presence of fistula in hospital and/or if a well trained provider performed a physical examination of the genital area. Morbidity studies not reporting or mentioning fistulae but including a robust design, a thorough physical exam of the genital area that reported cases of uterine prolapse were assumed to have zero cases of fistula, as it was assumed that if fistula had been found it would have been reported. Studies relying on women's self-reports were excluded because self-reports of reproductive morbidity have been shown to be unreliable $[13,15,16]$. We excluded studies that were conducted before 1990 or published before 1991. We included studies irrespective of sample size but studies without a denominator were excluded. If more than one paper provided results of the same study population, data were first extracted from the article with the greatest amount of information, and supplementary data extracted from the other papers if required.

Data were extracted by a single author (AJA) using a proforma and included information on region, study dates, study population, duration of fistula, type of fistula, risk factors, associated complications and denominators, how fistula were ascertained, sampling technique, number of women and number of deliveries. There are no good tools for looking at study quality in crosssectional studies, so study quality was assessed using a modified Ottawa-Newcastle score (http://www.ohri.ca/ programs/clinical_epidemiology/oxford.asp).

The studies reported on two types of populations of women: women of reproductive age and women with a recent pregnancy. In studies targeting women of reproductive age we calculated the prevalence of fistula per 1000 women of reproductive age. In studies where women were followed after end of pregnancy, we calculated the incidence of fistula per 1000 recently pregnant women (assuming that women were unlikely to have had fistula before getting pregnant). In all cases $95 \%$ confidence intervals were calculated using the binomial exact method.

Meta-analyses were conducted using the metaprop command from the $\mathrm{R} 2.15 .3$ package meta using a random-effects model [17]. Meta-analyses were conducted summarising the prevalence of fistula among women of reproductive age and the incidence of fistula in recently pregnant women. All studies were stratified by continent and by recruitment in hospital or in the community.

\section{Results}

The initial search of studies focussing on fistula found 9130 references after de-duplication, 367 of which were retained after title and abstract screening. From the 367 articles, six were found to have information on either prevalence or incidence of fistula [18-23]. A further 13

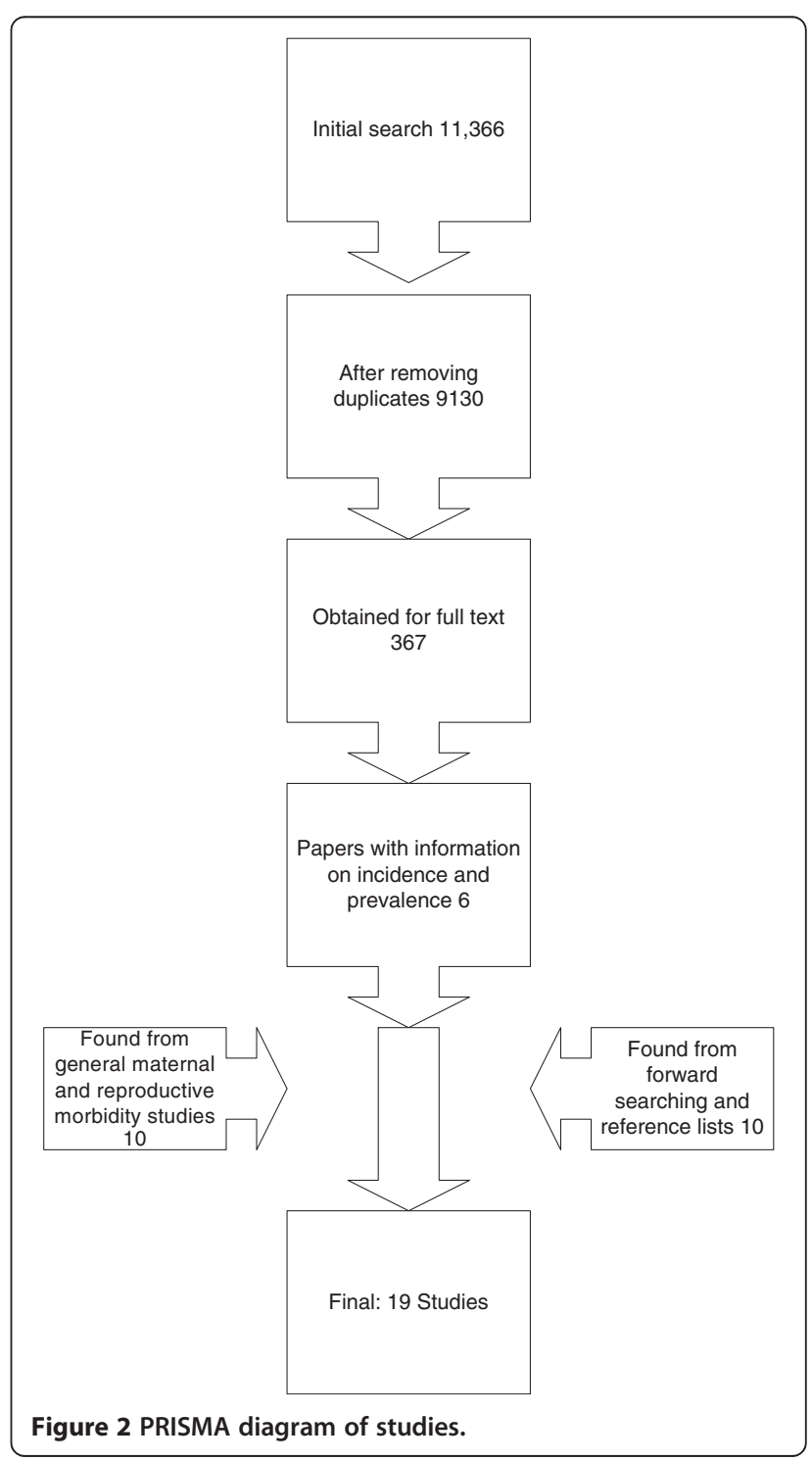


Table 1 Characteristics of studies reporting fistula prevalence included in the review

\begin{tabular}{|c|c|c|c|c|c|c|}
\hline Author & Study area & Study design & Assessment of fistula & Number of fistula & $\begin{array}{l}\text { Number of } \\
\text { women/ } \\
\text { pregnancies }\end{array}$ & $\begin{array}{l}\text { Prevalence } \\
\text { (per } 1000 \text { WRA) }\end{array}$ \\
\hline \multicolumn{7}{|l|}{ Community based studies } \\
\hline Muleta et al., 2008 [18] & $\begin{array}{l}\text { Seven rural administrative } \\
\text { regions in Ethiopia }\end{array}$ & $\begin{array}{l}\text { Cross-sectional survey of } \\
\text { obstetric fistula }\end{array}$ & $\begin{array}{l}\text { Women reporting leakage of } \\
\text { urine, faeces or both examined } \\
\text { in the health facilities }\end{array}$ & 44 (untreated) & 19,153 & $1.62(1.53,2.64)$ \\
\hline Walraven et al., 2001 [24] & $\begin{array}{l}\text { Random sample of } 20 \text { rural } \\
\text { villages in Farafenni, The } \\
\text { Gambia }\end{array}$ & $\begin{array}{l}\text { Census of all women aged 15-54 } \\
\text { for reproductive morbidity }\end{array}$ & $\begin{array}{l}\text { External, vaginal speculum and } \\
\text { bimanual pelvic examination by } \\
\text { female gynaecologist }\end{array}$ & 1 & 1,038 & $0.95(0.02,5.26)$ \\
\hline Kulkarni, 2007 [35] & $\begin{array}{l}\text { Six PHC areas (urban and } \\
\text { rural) in Maharashtra, India }\end{array}$ & $\begin{array}{l}\text { Cross sectional survey of } \\
\text { non-pregnant, ever married women } \\
\text { with proven fertility } \\
\text { for reproductive morbidity }\end{array}$ & $\begin{array}{l}\text { Clinical examination but } \\
\text { unspecified what or by whom }\end{array}$ & 1 & 1,167 & $0.86(0.02,4.8)$ \\
\hline Bhatia et al., 1997 [19] & $\begin{array}{l}\text { Villages ( } 25 \% \text { urban, } 75 \% \text { rural) } \\
\text { with at least } 500 \text { people in } \\
\text { Karnataka, India }\end{array}$ & $\begin{array}{l}\text { Cross sectional study of all eligible } \\
\text { women under } 35 \text { with a child } \\
\text { under } 5 \text { for reproductive morbidity }\end{array}$ & $\begin{array}{l}\text { External, vaginal speculum and } \\
\text { bimanual pelvic examination by } \\
\text { female gynaecologist }\end{array}$ & 1 & 385 & $2.6(0.07,14.39)$ \\
\hline Younis et al., 1993 [29] & $\begin{array}{l}\text { Two rural villages in Giza, } \\
\text { Egypt }\end{array}$ & $\begin{array}{l}\text { Cross sectional study of } \\
\text { reproductive morbidity in } \\
\text { ever-married, non pregnant } \\
\text { women. }\end{array}$ & $\begin{array}{l}\text { Speculum and bimanual } \\
\text { examination by female } \\
\text { physicians [1] }\end{array}$ & 0 & 509 & $0.0(0.0,7.90)$ \\
\hline Deeb et al., 2003 [27] & Nabi Sheet, Lebanon & $\begin{array}{l}\text { Cross sectional study of } \\
\text { reproductive morbidity in ever } \\
\text { married, non-pregnant women }\end{array}$ & $\begin{array}{l}\text { Thorough inspection of external } \\
\text { genitalia, with speculum } \\
\text { conducted by female } \\
\text { physicians [1] }\end{array}$ & 0 & 506 & $0.0(0.0,7.3)$ \\
\hline Al-Riyami et al., 2007 [28] & Oman, Mixed & $\begin{array}{l}\text { National Health Survey } 2000 \text { aiming } \\
\text { to identify reproductive morbidity. } \\
\text { Multi-stage stratified probability- } \\
\text { sampling design of 1,968 households } \\
\text { with ever married, non-pregnant women }\end{array}$ & $\begin{array}{l}\text { Pelvic examination by a trained } \\
\text { physician [1] }\end{array}$ & 0 & 1,662 & $0.0(0.0,2.2)$ \\
\hline Al-Qutob, 2001 [26] & $\begin{array}{l}\text { Ain Al-Basha, Jordan. } \\
\text { Semi-urban }\end{array}$ & $\begin{array}{l}\text { Random sample of Jordanian } \\
\text { women }\end{array}$ & $\begin{array}{l}\text { Comprehensive physical and } \\
\text { pelvic examination conducted } \\
\text { by trained female physician, a } \\
\text { nurse/midwife and a laboratory } \\
\text { technician [1] }\end{array}$ & 0 & 379 & $0.0(0.0,9.7)$ \\
\hline Bulut et al., 1995 [25] & City of Istanbul, Turkey & $\begin{array}{l}\text { Systematic sample of non-pregnant, } \\
\text { ever married parous women who } \\
\text { had ever used contraception }\end{array}$ & $\begin{array}{l}\text { Physical examination by female } \\
\text { physician [1] }\end{array}$ & 0 & 696 & $0.0(0.0,5.3)$ \\
\hline Tehrani et al., 2011 [34] & Four provinces of Iran & $\begin{array}{l}\text { Multi-stage stratified probability- } \\
\text { sampling design of non-pregnant } \\
\text { non menopausal women 18-45 }\end{array}$ & $\begin{array}{l}\text { Comprehensive gynaecological } \\
\text { examination of all married } \\
\text { women including a speculum } \\
\text { examination [1] }\end{array}$ & 0 & 1117 & $0.0(0.0 .3 .3)$ \\
\hline
\end{tabular}


Table 1 Characteristics of studies reporting fistula prevalence included in the review (Continued)

\section{Studies with hospital based recruitment}

ljaiya and Aboyeji, 2004 [23] Ilorin, Nigeria, urban

Kalilani-Phiri et al., 2010 [21] Nine districts (urban and rural) in Malawi

Mabeya, 2004 [36]

West Pokot, Kenya. Rura
Hospital review of women with fistula repair Repair

Hospital record reviews from gynaecological, Repai

prenatal, obstetric wards and operating

theatres as well as fistula repair services.

Only women originating from nine

districts included

Hospital record review supplemented by

surgeons' notes. Cases of fistulae

Repair

presenting to the two rural hospitals that

are the main hospitals in the district-

[1] These studies were reproductive morbidity studies which did not state in the methods that they were investigating fistula, nor did they report any cases of fistula; however the type of examination used to identify other reproductive morbidities was assessed to have been sufficient that should there have been any cases of fistula they would have been identified. 
Table 2 Characteristics of studies reporting fistula incidence included in the review

\begin{tabular}{|c|c|c|c|c|c|c|}
\hline Author & Study area & Study design & Assessment of fistula & $\begin{array}{l}\text { Number of } \\
\text { fistula }\end{array}$ & $\begin{array}{l}\text { Number of women/ } \\
\text { pregnancies }\end{array}$ & $\begin{array}{l}\text { Incidence (per } 1000 \\
\text { pregnant women) }\end{array}$ \\
\hline \multicolumn{7}{|l|}{ Community based studies } \\
\hline $\begin{array}{l}\text { Vangeenderhuysen et al., } \\
2001 \text { [22] }\end{array}$ & $\begin{array}{l}\text { Eight centres (urban and } \\
\text { rural) in six countries in } \\
\text { West Africa }\end{array}$ & $\begin{array}{l}\text { Prospective cohort study of all } \\
\text { pregnant women found by a } \\
\text { door to door census of households } \\
\text { followed up from antepartum to } \\
\text { two months postpartum. }\end{array}$ & $\begin{array}{l}\text { Women reporting gynaecological } \\
\text { problems. Fistula assessed at last } \\
\text { contact } 60 \text { days after delivery }\end{array}$ & 2 & 19,694 & $0.10(0.01,0.3)$ \\
\hline Ferdous et al., 2012 [33] & Matlab, Bangladesh. Rural & $\begin{array}{l}\text { Prospective cohort of all women } \\
\text { with obstetric complications, a } \\
\text { perinatal death or caesarean } \\
\text { section, and random sample of } \\
\text { women with uncomplicated births. }\end{array}$ & $\begin{array}{l}\text { Physical examination at health } \\
\text { centre from six to nine weeks } \\
\text { postpartum }\end{array}$ & 0 & 1,162 & $0(0,3.17)$ \\
\hline Fronczak et al., 2005 [20] & $\begin{array}{l}\text { Urban slums in Dhaka, } \\
\text { Bangladesh }\end{array}$ & $\begin{array}{l}\text { Prospective community-based study } \\
\text { of women completing at least seven } \\
\text { months of pregnancy. Women excluded } \\
\text { if birth identified more than } 21 \text { days } \\
\text { postpartum. Sample selected using } \\
\text { multi-stage probability. }\end{array}$ & $\begin{array}{l}\text { Physical exam conducted by } \\
\text { female physicians conducted } \\
\text { one-month postpartum }\end{array}$ & 0 & 557 & $0(0.0 .6 .6)$ \\
\hline \multicolumn{7}{|c|}{ Studies with hospital based recruitment } \\
\hline Filippi et al., 2007 [30] & $\begin{array}{l}\text { Seven public urban and rural } \\
\text { hospitals in Burkina Faso }\end{array}$ & $\begin{array}{l}\text { All women with severe obstetric } \\
\text { complications delivering in hospitals } \\
\text { and two controls per case. Interviews } \\
\text { conducted at } 3,6 \text {, and } 12 \text { months } \\
\text { after pregnancy. }\end{array}$ & Medical examinations & 1 & 1,014 & $0.99(0.03,5.48)$ \\
\hline Filippi et al., 2010 [31] & $\begin{array}{l}\text { Cotonou, Porto Novo and } \\
\text { neighbouring communities } \\
\text { in south Benin }\end{array}$ & $\begin{array}{l}\text { Prospective cohort study of women } \\
\text { with severe obstetric complications } \\
\text { and a sample of women with } \\
\text { uncomplicated childbirth. }\end{array}$ & $\begin{array}{l}\text { Medical examination with } \\
\text { obstetricians }\end{array}$ & 1 & 709 & $1.41(0.04,7.83)$ \\
\hline Prual et al., 1998 [32] & Niamey city, Niger. Urban & $\begin{array}{l}\text { All deliveries in six maternity wards, } \\
\text { and all complications referred to the } \\
\text { two referral maternity wards occurring } \\
\text { from } 28^{\text {th }} \text { week antenatal to } 42^{\text {nd }} \text { day } \\
\text { postpartum. }\end{array}$ & Medical examinations & 2 & 4,081 & $0.49(0.06,1.77)$ \\
\hline
\end{tabular}




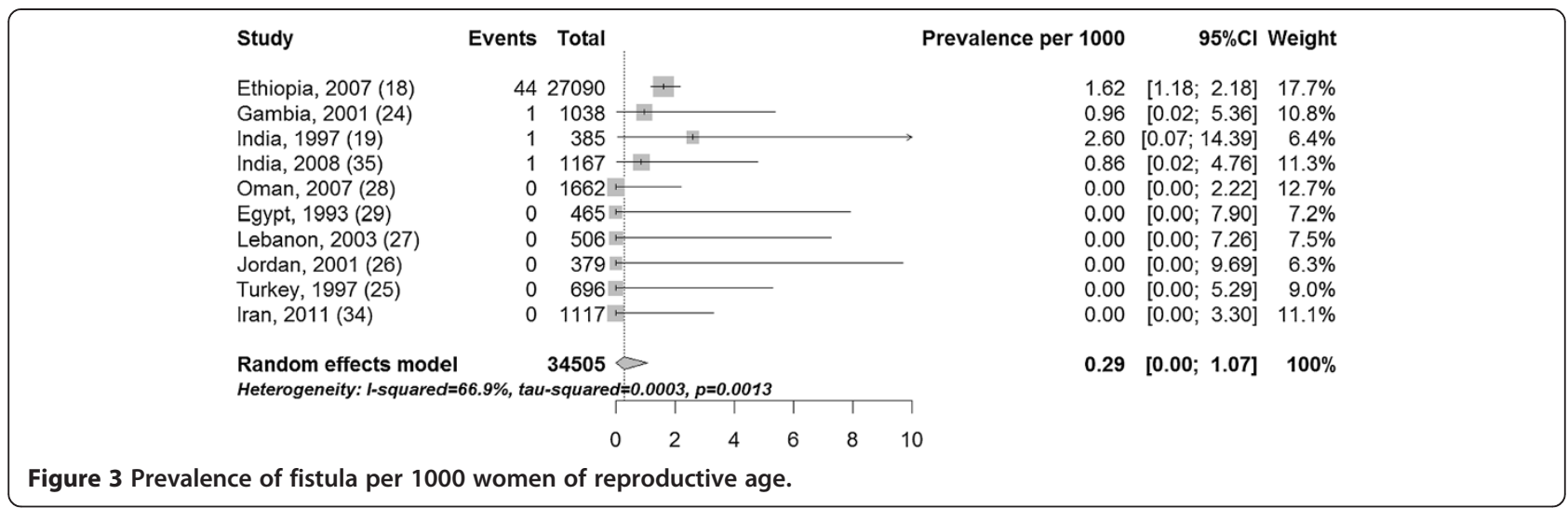

studies [24-34] were found from searching general maternal and reproductive morbidity studies (including three from reference lists and forward citation searching [34-36]) (Figure 2).

Of the 19 studies, 13 were community-based; seven of which reported on fistula [18-20,22,24,33,35] and six did not mention fistula anywhere in the paper. Ten community-based studies reported the prevalence of fistula among women of reproductive age (Table 1) and three reported the incidence among recently pregnant women (Table 2). Six studies recruited women in hospital and followed them for 30 days or more after the end of pregnancy (Table 2). Three studies [21,23,36], report the prevalence of fistula among women after having fistula repairs. These studies were included because it was possible to understand the population that these women came from, and have a denominator (Table 1). The other three studies reported the incidence of fistula among women after giving birth or miscarrying in hospital. These studies recruited women with obstetric complications as well as a sample of women without complications [30-32].
Three community-based studies were from sub-Saharan Africa [18,22,24], four were from South Asia [19,20,33,35], two were from North Africa [28,29], three from the Middle East [26,27,34], and one from Turkey [25]. All six studies using hospital-based recruitment were from subSaharan Africa [21,23,30-32,36].

The prevalence of fistula in community-based studies ranged from 0 to 1.62 per 1000 women of reproductive age with a median of 0 per 1000 (Figure 3). The pooled prevalence of fistula in community-based studies was 0.29 (10 studies including 34,505 participants 95\% CI $0.00,1.07)$ per 1000 women of reproductive age (Figure 3). The pooled estimate for sub-Saharan Africa and South Asia was 1.13 (4 studies with 29,680 participants $95 \%$ CI $0.72,1.61$ ) per 1000 women of reproductive age (Figure 4). By continent Sub-Saharan Africa had an overall prevalence of 1.60 (two studies including 28,128 participants $95 \%$ CI $1.16,2.10$ ) per 1000 women of reproductive age and South Asia had a prevalence of 1.20 (two studies with 1552 participants 95\% CI 0.10 , 3.63) per 1000 women of reproductive age (Figure 4). Because all studies from the Middle-East and North

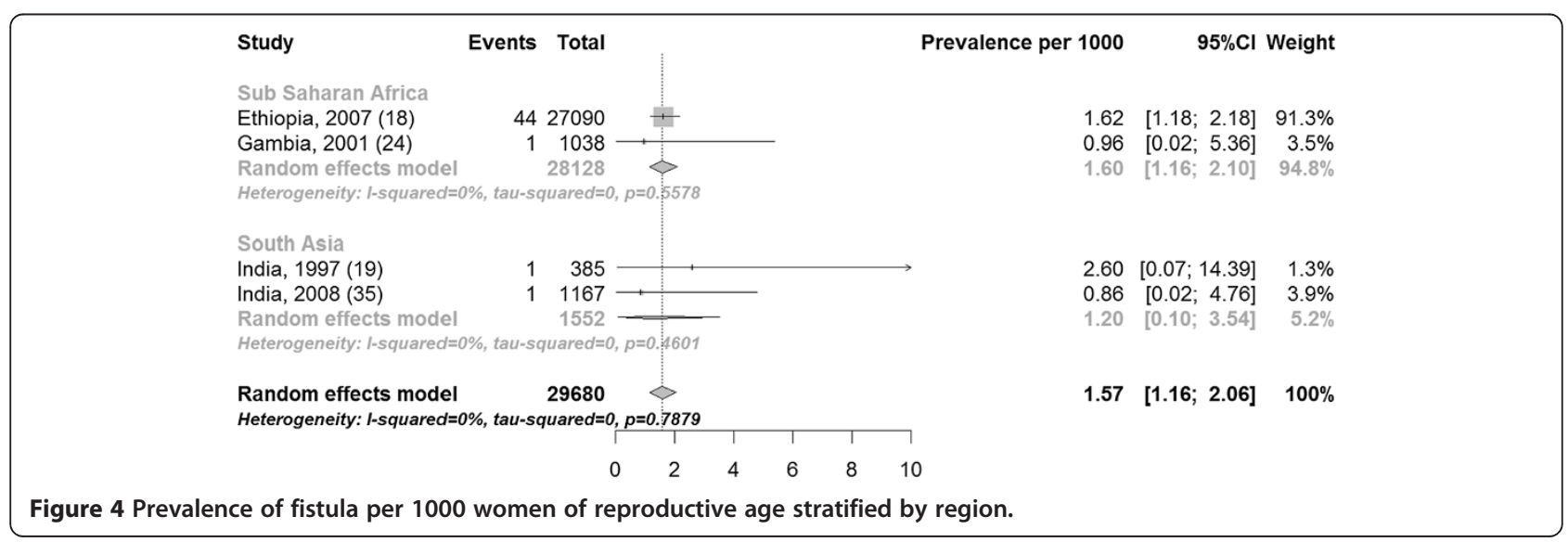




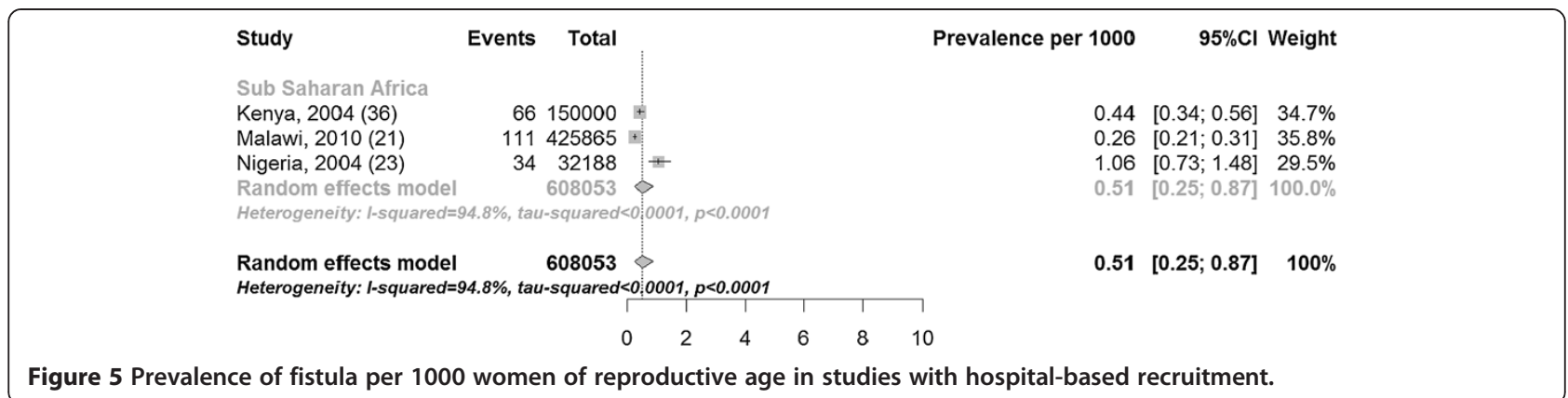

Africa had zero events, it is impossible for the metaanalysis to provide a meaningful estimate due to the manner with which zero prevalence studies are dealt with (http://cran.r-project.org/web/packages/meta/meta.pdf).

The prevalence of fistula in studies with hospital-based recruitment ranged from 0.26 to 1.06 per 1000 women of reproductive age, with a median of 0.44 per 1000 women of reproductive age. The pooled estimate of the prevalence of fistula in hospital was 0.51 (three studies with 608,053 participants 95\% CI 0.25, 0.87) per 1000 women of reproductive age (Figure 5).

The pooled incidence of fistula in community-based studies was 0.09 (three studies with 21,413 participants $0.01,0.25)$ per 1000 recently pregnant women (Figure 6) and in hospital-based studies 0.66 (three studies including 5804 participants $0.16,1.48)$ per 1000 recently pregnant women (Figure 7).

The I [2] values varied substantially by stratum, ranging from $0 \%$ in community-based (Figure 6) and hospitalbased (Figure 7) incidence studies to $94.8 \%$ in prevalence studies with hospital based recruitment (Figure 5). Study quality in the modified Ottawa-Newcastle score table is shown in Table 3. All studies had a cross-sectional or cohort design.

Only two studies reported information on duration of fistula: one found a median of eight years [18], and the other a median of three years [21]. No community based studies reported on the mode of delivery of the women, or on the cause of fistula.

\section{Discussion}

Our comprehensive systematic review found that fewer than 1 per 1000 women of reproductive age in low and middle income countries suffer from fistula; this figure rises to 1.57 per 1000 when only data from sub-Saharan Africa and South Asia is used. The number of new cases of fistula ranged from 0.09 per 1000 recently pregnant women in community-based studies to 0.66 per 1000 pregnancies in hospital-based studies.

The WHO has suggested that over two million women, mostly from sub-Saharan African and Asian countries, have fistula [1,37]. Given an estimated population of 645 million women of reproductive age in sub-Saharan Africa and South Asia in 2010 (http://esa.un.org/wpp/unpp/ p2k0data.asp), this would suggest that 3 per 1000 women of reproductive age have a fistula, which is considerably higher than our estimate for low and middle income countries. There were too few studies in our review to arrive at robust estimates of the prevalence of fistula by continent, but even the highest estimates for sub-Saharan Africa (1.62 per 1000 women of reproductive age in Ethiopia) or South Asia (2.6 per 1000 in India) fall well

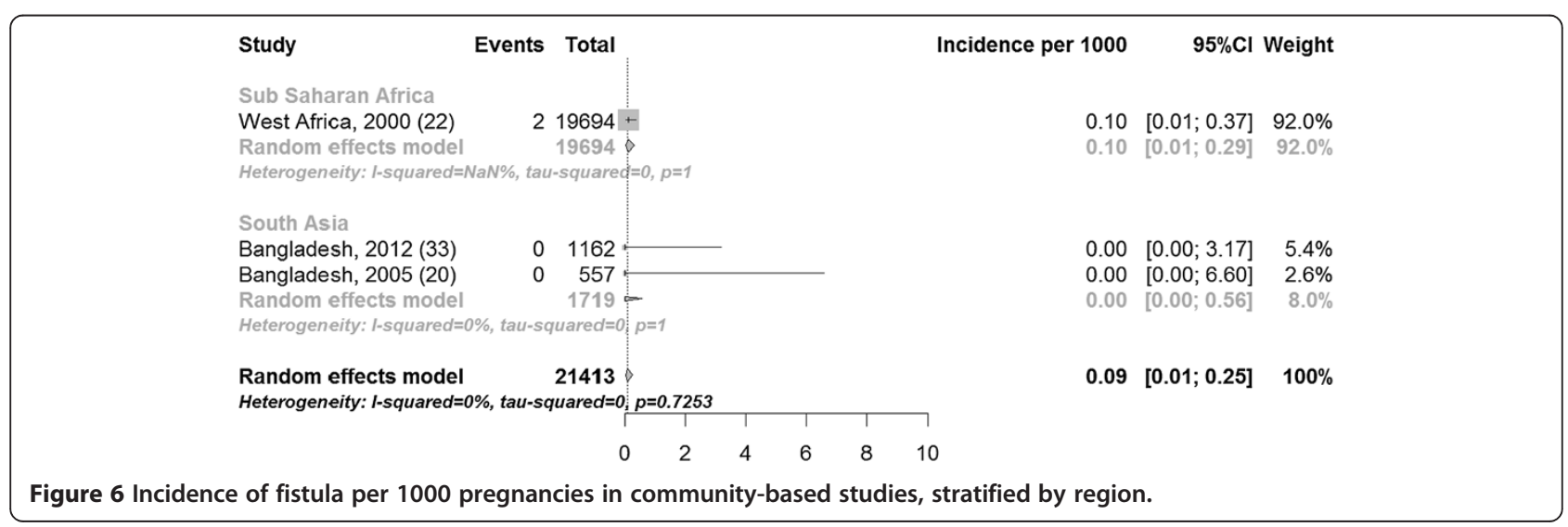




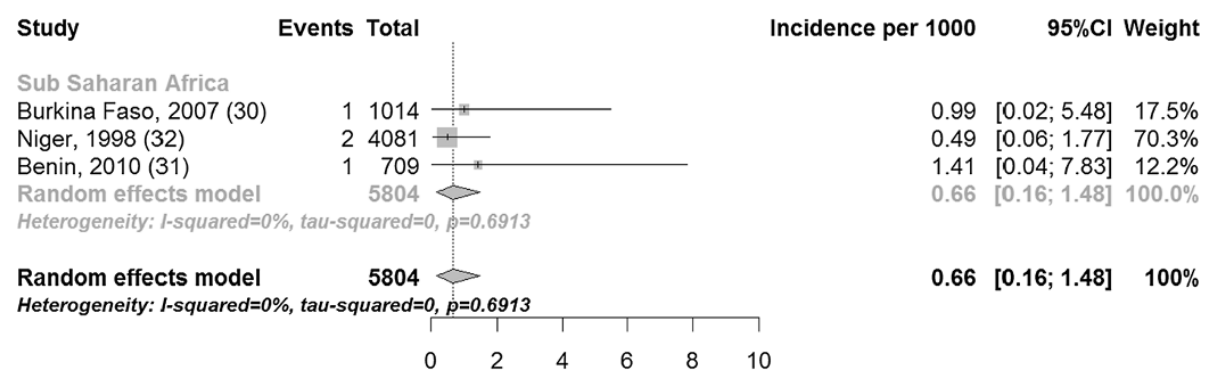

Figure 7 Incidence of fistula per 1000 pregnant women in studies with hospital-based recruitment.

short of the WHO estimates. One study [22] estimated an incidence of 1.239 per 1000 deliveries in rural regions and used this to approximate 33,451 new fistula a year in Sub Saharan Africa. This was based on 2 fistulae found in the "rural region" in the MOMA study. Elsewhere they refer to these regions as "small towns" [38]. They then used the sample of 2 fistulae per 1543 live births to estimate the overall incidence for sub-Saharan Africa. This approach is likely to have over-estimated the number of fistulae patients. First because a substantial proportion of African women now live in cities where the risk of fistulae is likely to be lower than in smaller towns or rural areas; second because the denominator does not include the urban women in larger cities for whom there were no fistulae occurrence.

Overall, we estimate that just over one million women may have a fistula in sub-Saharan Africa and South Asia, and that there are over 6000 new cases per year in these two world regions. Given the devastating consequences of fistula for women and their families, this represents a very substantial burden.

It is possible that community based studies represent an underestimate of the prevalence of fistula, as fistulae are generally more commonly found in regions where there is no access to obstetric care, and may be difficult to reach. These women may have been missed in the studies included here, and the estimates provided here may represent a lower bound estimate of prevalence. However both the studies in Ethiopia [18] and the Gambia [24] were conducted in rural areas, and both studies showed very low estimates of prevalence (1.62 and 0.96 respectively).

Our search identified 13 additional studies that would not have been found had the search been restricted to fistula only. This was particularly relevant for communitybased prevalence studies, where the specific fistula search only identified four studies, compared to nine when the search was expanded to maternal and reproductive morbidity studies. Inclusion of studies that did not mention fistula could bias the results downwards since it is not certain that women were examined for fistula. However, our strategy of including only studies for which a thorough gynaecological examination was conducted should have ensured that fistula would have been diagnosed and reported if present. Additionally, we only included studies which elicited uterine prolapse, since this implied a thorough examination. Because fistula is a rare condition, it is important to take account of studies that did not find any fistulae, in the same way that studies with negative findings are crucial in systematic reviews of treatment effectiveness [39].

We were unable to draw solid conclusions about regional variations in the prevalence or incidence of fistula. We only found three community based studies from sub-Saharan Africa and four community-based studies from South Asia (all from India or Bangladesh). Many studies were from very select communities and it is uncertain whether these findings are generalisable to Africa and Asia as a whole. The heterogeneity in prevalence or incidence of fistula in community-based studies was very low however, suggesting that the prevalence and incidence of fistula was uniformly low across all study sites.

It is difficult to estimate the duration of fistula from the reviewed studies because only two papers provided an estimate. However, given that one of these from Malawi had a median duration of three years [21], and the other from Ethiopia [18] had a median duration of eight years, it seems that women can live with this condition for a very long time, in some contexts. Other studies have shown that women live with these conditions for years before presenting for fistula repair, sometimes as long as over 20 years [10]. Additionally there was a lack of information on the mode of delivery and cause of the fistula in the community based studies, meaning that it is possible that some women suffered a fistula from causes other than prolonged or obstructed labour.

The low prevalence and incidence of fistula among women recruited in hospital is somewhat unexpected, since women seeking care from hospitals tend to be selfselecting because they are ill. The low incidence among 
Table 3 Sources of risk of bias in included studies

\begin{tabular}{|c|c|c|c|c|c|c|c|}
\hline \multirow[b]{2}{*}{ Study: } & \multicolumn{3}{|l|}{ Selection } & \multirow{2}{*}{$\begin{array}{l}\text { Comparability } \\
\text { Comparability } \\
\text { of cases and } \\
\text { non-cases }\end{array}$} & \multicolumn{3}{|l|}{ Outcome } \\
\hline & $\begin{array}{l}\text { What is the case } \\
\text { definition? (Condition } \\
\text { of interest) }\end{array}$ & $\begin{array}{l}\text { Representativeness of } \\
\text { the study population }\end{array}$ & Selection of non cases & & $\begin{array}{l}\text { Assessment } \\
\text { of outcome }\end{array}$ & $\begin{array}{l}\text { Was study long enough } \\
\text { to ensure cases would } \\
\text { be found }\end{array}$ & Differential follow up? \\
\hline $\begin{array}{l}\text { Muleta et al., } 2008 \\
\text { [18] }\end{array}$ & $\begin{array}{l}\text { Obstetric fistula treated } \\
\text { and untreated }\end{array}$ & $\begin{array}{l}\text { Population based } \\
\text { sample of seven } \\
\text { administrative } \\
\text { regions of rural } \\
\text { Ethiopia }\end{array}$ & $\begin{array}{l}\text { Only women reporting } \\
\text { leaking examined, therefore } \\
\text { it is possible that some } \\
\text { women may have been } \\
\text { counted as non cases }\end{array}$ & $\begin{array}{l}\text { All from same } \\
\text { population }\end{array}$ & $\begin{array}{l}\text { Sufficient physical } \\
\text { exam }\end{array}$ & $\begin{array}{l}\text { As sample was women } \\
\text { of reproductive age, } \\
\text { some women will have } \\
\text { only just given birth } \\
\text { and it is possible they } \\
\text { may have not yet } \\
\text { developed fistula }\end{array}$ & Do not state \\
\hline $\begin{array}{l}\text { Walraven et al., } \\
2001 \text { [24] }\end{array}$ & $\begin{array}{l}\text { Obstetric morbidities } \\
\text { including fistula }\end{array}$ & $\begin{array}{l}\text { Population based } \\
\text { rural region }\end{array}$ & $\begin{array}{l}\text { All women invited for a } \\
\text { physical examination }\end{array}$ & $\begin{array}{l}\text { All from same } \\
\text { population }\end{array}$ & $\begin{array}{l}\text { Sufficient physical } \\
\text { exam }\end{array}$ & $\begin{array}{l}\text { As sample was women } \\
\text { of reproductive age, } \\
\text { some women will have } \\
\text { only just given birth and } \\
\text { it is possible they may } \\
\text { have not yet developed } \\
\text { fistula }\end{array}$ & $\begin{array}{l}28 \% \text { of sample did not } \\
\text { have examination }\end{array}$ \\
\hline Kulkarni, 2007 [35] & $\begin{array}{l}\text { Obstetric morbidities } \\
\text { including fistula }\end{array}$ & Population based & $\begin{array}{l}\text { Included all women } \\
\text { examined }\end{array}$ & $\begin{array}{l}\text { All from same } \\
\text { population }\end{array}$ & $\begin{array}{l}\text { Sufficient physical } \\
\text { exam }\end{array}$ & $\begin{array}{l}\text { Women with children at } \\
\text { least six months } \\
\text { examined so assumption } \\
\text { is that it would be six } \\
\text { months postpartum }\end{array}$ & $\begin{array}{l}25 \% \text { of sample women } \\
\text { did not have examination }\end{array}$ \\
\hline $\begin{array}{l}\text { Bhatia et al., } 1997 \\
\text { [19] }\end{array}$ & $\begin{array}{l}\text { Gynecological morbidity } \\
\text { including fistula }\end{array}$ & Population based & $\begin{array}{l}\text { Included all women } \\
\text { examined }\end{array}$ & $\begin{array}{l}\text { All from same } \\
\text { population }\end{array}$ & $\begin{array}{l}\text { Sufficient physical } \\
\text { exam }\end{array}$ & $\begin{array}{l}\text { Women had exam after } \\
\text { one year so long enough } \\
\text { for fistula to develop }\end{array}$ & $\begin{array}{l}5 \% \text { lost to follow up, } \\
6 \% \text { not examined }\end{array}$ \\
\hline $\begin{array}{l}\text { Younis et al., } 1993 \\
\text { [29] }\end{array}$ & $\begin{array}{l}\text { Gynaecological and } \\
\text { related morbidities, but } \\
\text { do not state that they } \\
\text { looked for fistula }\end{array}$ & Population based & $\begin{array}{l}\text { Included all women } \\
\text { examined }\end{array}$ & No cases & $\begin{array}{l}\text { Sufficient physical } \\
\text { exam }\end{array}$ & $\begin{array}{l}\text { Women who were ever } \\
\text { married and not } \\
\text { pregnant, so it is } \\
\text { possible they may have } \\
\text { not yet developed fistula }\end{array}$ & Do not state \\
\hline Deeb et al., 2003 [27] & $\begin{array}{l}\text { Gynaecological and } \\
\text { related morbidities, but } \\
\text { do not state that they } \\
\text { looked for fistula }\end{array}$ & Population based & $\begin{array}{l}\text { Included all women } \\
\text { examined }\end{array}$ & No cases & $\begin{array}{l}\text { Sufficient physical } \\
\text { exam }\end{array}$ & $\begin{array}{l}\text { Women who were ever } \\
\text { married and not pregnant, } \\
\text { so it is possible they may } \\
\text { have not yet developed } \\
\text { fistula }\end{array}$ & $\begin{array}{l}9 \% \text { did not have } \\
\text { examination }\end{array}$ \\
\hline $\begin{array}{l}\text { Al-Riyami et al., } 2007 \\
\text { [28] }\end{array}$ & $\begin{array}{l}\text { Gynaecological and } \\
\text { related morbidities, but } \\
\text { do not state that they } \\
\text { looked for fistula }\end{array}$ & $\begin{array}{l}\text { Population based } \\
\text { from national } \\
\text { survey }\end{array}$ & $\begin{array}{l}\text { Included all women } \\
\text { examined }\end{array}$ & No cases & $\begin{array}{l}\text { Sufficient physical } \\
\text { exam }\end{array}$ & $\begin{array}{l}\text { As sample was women of } \\
\text { reproductive age, it is } \\
\text { possible they may have } \\
\text { not yet developed fistula }\end{array}$ & Do not state \\
\hline Al-Qutob, 2001 [26] & $\begin{array}{l}\text { Gynaecological and } \\
\text { related morbidities, but } \\
\text { do not state that they } \\
\text { looked for fistula }\end{array}$ & Population based & $\begin{array}{l}\text { Included all women } \\
\text { examined }\end{array}$ & No cases & $\begin{array}{l}\text { Sufficient physical } \\
\text { exam }\end{array}$ & $\begin{array}{l}\text { Women who were ever } \\
\text { married and not pregnant, } \\
\text { so it is possible they may } \\
\text { have not yet } \\
\text { developed fistula }\end{array}$ & $\begin{array}{l}10.7 \% \text { did not have } \\
\text { examination }\end{array}$ \\
\hline
\end{tabular}


Table 3 Sources of risk of bias in included studies (Continued)

\begin{tabular}{|c|c|c|c|c|c|c|c|}
\hline Bulut et al., 1995 [25] & $\begin{array}{l}\text { Gynaecological and } \\
\text { related morbidities, } \\
\text { but do not state } \\
\text { that they looked } \\
\text { for fistula }\end{array}$ & $\begin{array}{l}\text { Population based, but } \\
\text { in Istanbul which may } \\
\text { not be representative } \\
\text { of Turkey as a whole. } \\
\text { Additionally only } \\
\text { included women who } \\
\text { had ever used } \\
\text { contraception }\end{array}$ & $\begin{array}{l}\text { Included all women } \\
\text { examined }\end{array}$ & No cases & $\begin{array}{l}\text { Sufficient physical } \\
\text { exam }\end{array}$ & $\begin{array}{l}\text { Unclear how long women } \\
\text { were followed up for } \\
\text { after pregnancy }\end{array}$ & $\begin{array}{l}5 \% \text { did not have } \\
\text { examination }\end{array}$ \\
\hline $\begin{array}{l}\text { Tehrani et al., } 2011 \\
\text { [34] }\end{array}$ & $\begin{array}{l}\text { Gynaecological and } \\
\text { related morbidities, } \\
\text { but do not state } \\
\text { that they looked for } \\
\text { fistula }\end{array}$ & Population based & $\begin{array}{l}\text { Included all women } \\
\text { examined }\end{array}$ & No cases & $\begin{array}{l}\text { Sufficient physical } \\
\text { exam }\end{array}$ & $\begin{array}{l}\text { All women from } 18-45 \\
\text { who were not pregnant, } \\
\text { so it is possible some may } \\
\text { not have had time for } \\
\text { fistula to form }\end{array}$ & 119 dropped out \\
\hline $\begin{array}{l}\text { ljaiya and Aboyeji, } \\
2004 \text { [23] }\end{array}$ & Obstetric fistula & $\begin{array}{l}\text { Hospital record review } \\
\text { of fistula repairs with } \\
\text { details about reference } \\
\text { population }\end{array}$ & Case series of repairs & No non cases & $\begin{array}{l}\text { Physical exam } \\
\text { and treatment }\end{array}$ & $\begin{array}{l}\text { All women already had } \\
\text { fistula. Possible that } \\
\text { women missed who } \\
\text { did not present for } \\
\text { treatment }\end{array}$ & N/A \\
\hline $\begin{array}{l}\text { Kalilani-Phiri et al., } \\
2010 \text { [21] }\end{array}$ & Obstetric fistula & $\begin{array}{l}\text { Hospital record review } \\
\text { with details of } \\
\text { population it came } \\
\text { from, however } \\
\text { researchers eliminated } \\
\text { all cases not originating } \\
\text { in the region. }\end{array}$ & Case series of repairs & No non cases & $\begin{array}{l}\text { Physical exam } \\
\text { and treatment }\end{array}$ & $\begin{array}{l}\text { All women already had } \\
\text { fistula. Possible that } \\
\text { women missed who did } \\
\text { not present for treatment }\end{array}$ & N/A \\
\hline Mabeya, 2004 [36] & Obstetric fistula & $\begin{array}{l}\text { Hospital record review } \\
\text { of fistula repairs with } \\
\text { details about reference } \\
\text { population }\end{array}$ & Case series of repairs & No non cases & $\begin{array}{l}\text { Physical exam } \\
\text { and treatment }\end{array}$ & $\begin{array}{l}\text { All women already had } \\
\text { fistula. Possible that } \\
\text { women missed who did } \\
\text { not present for treatment }\end{array}$ & N/A \\
\hline $\begin{array}{l}\text { Vangeenderhuysen } \\
\text { et al., } 2001 \text { [22] }\end{array}$ & $\begin{array}{l}\text { Obstetric morbidities } \\
\text { including fistula }\end{array}$ & Population based & $\begin{array}{l}\text { Included all women } \\
\text { examined }\end{array}$ & $\begin{array}{l}\text { All from same } \\
\text { population }\end{array}$ & $\begin{array}{l}\text { Sufficient physical } \\
\text { exam }\end{array}$ & $\begin{array}{l}\text { Followed up to } 60 \text { days } \\
\text { after birth }\end{array}$ & $5.7 \%$ loss to follow up \\
\hline $\begin{array}{l}\text { Ferdous et al., } 2012 \\
\text { [33] }\end{array}$ & $\begin{array}{l}\text { All short and long term } \\
\text { postpartum morbidities } \\
\text { including fistula }\end{array}$ & $\begin{array}{l}\text { Women with morbidities } \\
\text { and random sample of } \\
\text { all women }\end{array}$ & $\begin{array}{l}\text { Included all women } \\
\text { examined }\end{array}$ & $\begin{array}{l}\text { All from same } \\
\text { population }\end{array}$ & $\begin{array}{l}\text { Sufficient physical } \\
\text { exam }\end{array}$ & $\begin{array}{l}\text { Examined 6-9 weeks } \\
\text { postpartum }\end{array}$ & $\begin{array}{l}4.1 \% \text { lost to follow up } \\
\text { and } 6.1 \% \text { did not have } \\
\text { examination }\end{array}$ \\
\hline $\begin{array}{l}\text { Fronczak et al., } 2005 \\
\text { [20] }\end{array}$ & $\begin{array}{l}\text { Obstetric morbidities } \\
\text { including fistula }\end{array}$ & Population based & $\begin{array}{l}\text { All women examined, } \\
\text { but women who may } \\
\text { have had fistula followed } \\
\text { up longer }\end{array}$ & $\begin{array}{l}\text { All from same } \\
\text { population }\end{array}$ & $\begin{array}{l}\text { Sufficient physical } \\
\text { exam }\end{array}$ & $\begin{array}{l}\text { Women feared to have } \\
\text { fistula followed up one } \\
\text { month postpartum }\end{array}$ & $\begin{array}{l}63 \% \text { did not have } \\
\text { examination }\end{array}$ \\
\hline $\begin{array}{l}\text { Filippi et al., } 2007 \\
\text { [30] }\end{array}$ & $\begin{array}{l}\text { Severe obstetric } \\
\text { complications } \\
\text { including fistula }\end{array}$ & $\begin{array}{l}\text { Women with } \\
\text { complications over- } \\
\text { represented but also } \\
\text { had follow up of women }\end{array}$ & All women examined & $\begin{array}{l}\text { All from same } \\
\text { population }\end{array}$ & $\begin{array}{l}\text { Sufficient physical } \\
\text { exam }\end{array}$ & $\begin{array}{l}\text { Women had follow up } \\
\text { at six months }\end{array}$ & $\begin{array}{l}11 \% \text { only had either } \\
\text { interview or physical } \\
\text { exam at six months }\end{array}$ \\
\hline
\end{tabular}


Table 3 Sources of risk of bias in included studies (Continued)

\begin{tabular}{|c|c|c|c|c|c|c|c|}
\hline $\begin{array}{l}\text { Filippi et al., } 2010 \\
\text { [31] }\end{array}$ & $\begin{array}{l}\text { Severe obstetric } \\
\text { complications } \\
\text { including fistula }\end{array}$ & $\begin{array}{l}\text { Women with } \\
\text { complications over- } \\
\text { represented but also } \\
\text { had follow up of women } \\
\text { with uncomplicated birth }\end{array}$ & All women examined & $\begin{array}{l}\text { All from same } \\
\text { population }\end{array}$ & $\begin{array}{l}\text { Sufficient physical } \\
\text { exam }\end{array}$ & $\begin{array}{l}\text { Women had follow up } \\
\text { at six months }\end{array}$ & $\begin{array}{l}32 \% \text { of women did not } \\
\text { have follow up at six } \\
\text { months }\end{array}$ \\
\hline Prual et al., 1998 [32] & $\begin{array}{l}\text { Severe obstetric } \\
\text { complications } \\
\text { including fistula }\end{array}$ & $\begin{array}{l}\text { Women with complications } \\
\text { over-represented but also } \\
\text { had follow up of women } \\
\text { with uncomplicated birth }\end{array}$ & All women examined & $\begin{array}{l}\text { All from same } \\
\text { population }\end{array}$ & $\begin{array}{l}\text { Sufficient physical } \\
\text { exam }\end{array}$ & $\begin{array}{l}\text { Unclear how long women } \\
\text { were followed up for after } \\
\text { pregnancy so it is possible } \\
\text { they may have not yet } \\
\text { developed fistula }\end{array}$ & Do not state \\
\hline
\end{tabular}


women followed in the community after admission to hospital with near-miss obstetric morbidity ( 0.9 per 1000 and 1.4 per 1000) $[30,31]$ is particularly surprising, since this sample would have included a substantial number of women with a prolonged and complicated labour. For example in Benin $27.1 \%$ of women had near-miss due to dystocia, which would have included women with both obstructed and prolonged labour [31]. Because these women were recruited in hospital, a timely caesarean section may have prevented the fistula from developing. Reduced fertility is common in women with fistula (due to loss of vagina, amenorrhoea, not engaging in intercourse, and inability to have a live baby) $[2,7,9]$, and it is unlikely that women in the included incidence studies would have had a fistula before getting pregnant. Attention should be drawn to the fact that the metaanalysis included one study from Ethiopia that had $76.4 \%$ (Figure 3) or $91.3 \%$ of the weight in communitybased studies (Figure 4), possibly inflating the pooled prevalence estimate.

The low frequency of fistulae in any community make survey enquiries that specifically target the counting of fistula cases prohibitively expensive given the large sample sizes required. Still, all community based studies of reproductive health should explicitly ascertain and report the clinical presence or absence of fistula, even when the sample size is small. .

In many countries in sub-Saharan Africa there is an emphasis on building specialised fistula hospitals dedicated to the treatment of women suffering from fistula. Given the rarity of the condition and the high level of skills and training required for fistulae surgery, the results of this review suggest that the majority of the resources will always be better placed on prevention rather than cure. Strengthening maternal health services, creating conditions for better transportation and communication networks and training of local providers into the management of emergency complications, including with caesarean sections, would have the additional effect of providing care for other causes of maternal and perinatal mortality and morbidity.

The relative rarity of fistula should not detract from their public health importance. The estimated 6000 new cases of fistula per year in sub-Saharan Africa and South Asia are a painful testament to the continued failure of health systems to manage labour complications effectively. Caesarean sections remain inaccessible to a large number of women in sub-Saharan Africa [40]. Delays in accessing caesarean sections, faulty techniques and lack of caesarean sections all contribute to the burden of fistula. The fact that fistula have virtually disappeared in high income countries suggest that they are entirely preventable. Given the seriousness of the condition, and the devastating consequences of fistula for women and their families, efforts should also be made to find these women and treat them.

\section{Conclusions}

Our study is the most comprehensive study of the burden of fistula to date, including study sources not generally used. Our findings suggest that the prevalence and incidence of fistula is relatively low. The low burden of fistula should not detract from their public health importance, however, given the preventability of the condition, and the devastating consequences of fistula. Future studies of fistula should include a description of the study population with defined denominators.

\section{Competing interests}

The author's declare that they have no competing interests.

\section{Authors' contributions}

AJA conducted search, extracted data, did analysis and wrote first draft of paper CR advised on methodology and commented on drafts CC commented on drafts and helped in writing of paper VF helped design study and commented on paper. All authors read and approved the final manuscript.

\section{Acknowledgements}

The authors would like to thank Doris Chou, Lale Say, and Herbert Peterson for their comments.

\section{Funding}

This research was funded through a grant made to the Child Health Epidemiology Reference Group (CHERG) by the Bill and Melinda Gates Foundation.

Received: 13 June 2013 Accepted: 9 December 2013

Published: 30 December 2013

\section{References}

1. WHO: Obstetric fistula: guiding principles for clinical management and programme development. Geneva: World Health Organization; 2006.

2. Wall LL, Arrowsmith SD, Briggs ND, Browning A, Lassey A: The obstetric vesicovaginal fistula in the developing world. Obste \& gyne survey 2005, 60(7 Suppl 1):S3-S51.

3. Danso KA, Martey JO, Wall LL, Elkins TE: The epidemiology of genitourinary fistulae in Kumasi, Ghana, 1977-1992. Int Urogynecol J Pelvic Floor Dysfunct 1996, 7(3):117-120.

4. Langkilde NC, Pless TK, Lundbeck F, Nerstrom B: Surgical repair of vesicovaginal fistulae-a ten-year retrospective study. Scand J Urol Nephrol 1999, 33(2):100-103.

5. Karateke A, Cam C, Ozdemir A, Guney B, Vatansever D, Celik C: Characteristics of obstetric fistulas and the need for a prognostic classification system. Archives of Med Sci 2010, 6(2):253-256.

6. Muleta M, Hamlin EC, Fantahun M, Kennedy RC, Tafesse B: Health and social problems encountered by treated and untreated obstetric fistula patients in rural Ethiopia. J Obstet Gynaecol Can 2008, 30(1):44-50.

7. Wall LL, Karshima JA, Kirschner C, Arrowsmith SD: The obstetric vesicovaginal fistula: characteristics of 899 patients from Jos, Nigeria. Am J Obstet Gynecol 2004, 190(4):1011-1019.

8. Browning A, Fentahun W, Goh JT: The impact of surgical treatment on the mental health of women with obstetric fistula. BJOG 2007, 114(11):1439-1441.

9. Hilton P, Ward A: Epidemiological and surgical aspects of urogenital fistulae: a review of 25 years' experience in southeast Nigeria. Int Urogynecol J Pelvic Floor Dysfunct 1998, 9(4):189-194.

10. Holme A, Breen M, MacArthur C: Obstetric fistulae: a study of women managed at the Monze Mission Hospital, Zambia. BJOG 2007, 114(8):1010-1017. 
11. Goh JT, Sloane KM, Krause HG, Browning A, Akhter S: Mental health screening in women with genital tract fistulae. BJOG 2005, 112(9):1328-1330.

12. Dolea C, AbouZhar C: Global Burden of Obstructed Labour in the Year 2000. Geneva: World Health Organisation; 2003. http://www.who.int/healthinfo/ statistics/bod_obstructedlabour.pd.

13. Stanton C, Holtz SA, Ahmed S: Challenges in measuring obstetric fistula. Int J Gynaecol Obstet 2007, 99(Suppl 1):S4-S9.

14. Leung TY, Chung TKH: Severe chronic morbidity following childbirth Best Prac Res Clin Obstet Gynaecol 2009, 23(3):401-423.

15. Ronsmans C, Achadi E, Cohen S, Zazri A: Women's recall of obstetric complications in south Kalimantan Indonesia. Stud Fam Plann 1997, 28(3):203-214

16. Filippi V, Ronsmans C, Gandaho T, Graham W, Alihonou E, Santos P: Women's reports of severe (near-miss) obstetric complications in Benin. Stud Fam Plann 2000, 31(4):309-324.

17. Borenstein M, Hedges LV, Higgins JPT, Rothstein HR: A basic introduction to fixed-effect and random-effects models for meta-analysis. Res Syn Methods 2010, 1(2):97-111.

18. Muleta M, Fantahun M, Tafesse B, Hamlin EC, Kennedy RC: Obstetric fistula in rural Ethiopia. East Afr Med J 2007, 84(11):525-533.

19. Bhatia JC, Cleland J, Bhagavan L, Rao NS: Levels and determinants of gynecological morbidity in a district of south India. Stud Fam Plann 1997, 28(2):95-103.

20. Fronczak N, Antelman G, Moran AC, Caulfield LE, Baqui AH: Delivery-related complications and early postpartum morbidity in Dhaka, Bangladesh. Int J of Gynecology \& Obstetrics 2005, 91(3):271-278.

21. Kalilani-Phiri LV, Umar E, Lazaro D, Lunguzi J, Chilungo A: Prevalence of obstetric fistula in Malawi. Int J Gynaecol Obstet 2010, 109(3):204-208.

22. Vangeenderhuysen C, Prual A, Ould el Joud D: Obstetric fistulae: incidence estimates for sub-Saharan Africa. Int J Gynaecol Obstet 2001, 73(1):65-66.

23. Ijaiya MA, Aboyeji PA: Obstetric urogenital fistula: the llorin experience Nigeria. West Afr J Med 2004, 23(1):7-9.

24. Walraven G, Scherf C, West B, Ekpo G, Paine K, Coleman R, Bailey R, Morison $L$ : The burden of reproductive-organ disease in rural women in The Gambia West Africa. Lancet 2001, 357(9263):1161-1167.

25. Bulut A, Filippi V, Marshall T, Nalbant H, Yolsal N, Graham W: Contraceptive choice and reproductive morbidity in Istanbul. Stud Fam Plann 1997, 28(1):35-43

26. Al-Qutob R, Mawajdeh S, Massad D: Can a home-based pelvic examination be used in assessing reproductive morbidity in population-based studies? A Jordanian experience. J Adv Nurs 2001, 33(5):603-612.

27. Deeb ME, Awwad J, Yeretzian JS, Kaspar HG: Prevalence of reproductive tract infections, genital prolapse, and obesity in a rural community in Lebanon. Bull World Health Organ 2003, 81(9):639-645.

28. Al-Riyami A, Afifi M, Morsi M, Mabry R: A national study of gynecological morbidities in Oman Effect of women's autonomy. Saudi Med J 2007, 28(6):881-890

29. Younis N, Khattab H, Zurayk H, el-Mouelhy M, Amin MF, Farag AM: A community study of gynecological and related morbidities in rural Egypt. Stud Fam Plann 1993, 24(3):175-186

30. Filippi V, Ganaba R, Baggaley RF, Marshall T, Storeng KT, Sombié I, Ouattara F, Ouedraogo T, Akoum M, Meda N: Health of women after severe obstetric complications in Burkina Faso: a longitudinal study. Lancet 2007, 370(9595):1329-1337.

31. Filippi V, Goufodji S, Sismanidis C, Kanhonou L, Fottrell E, Ronsmans C, Alihonou E, Patel V: Effects of severe obstetric complications on women's health and infant mortality in Benin. Trop Med Int Health 2010, 15(6):733-742.

32. Prual A, Huguet D, Garbin O, Rabe G: Severe obstetric morbidity of the third trimester, delivery and early puerperium in Niamey (Niger). Afr J Reprod Health 1998, 2(1):10-19.

33. Ferdous J, Ahmed A, Dasgupta SK, Jahan M, Huda FA, Ronsmans C, Koblinsky M, Chowdhury ME: Occurrence and determinants of postpartum maternal morbidities and disabilities among women in Matlab, Bangladesh. J Health and Pop Nutrition 2012, 30(2):143-158.

34. Tehrani RF: Reproductive morbidity among Iranian women; issues often inappropriately addressed in health seeking behaviors. BMC Public Health 2011, 11:863.
35. Kulkarni R: Magnitude and determinants of chronic obstetric morbidities in Nasik District in Maharashtra. Indian Council for Medical Research 2007 2007. Available at: www.icmrnicin/annual/2007-08/nirrh/chapter5pdf 2007.

36. Mabeya HM: Characteristics of women admitted with obstetric fistula in the rural hospitals in west Pokot, Kenya. Postgraduate training course in reproductive health 2004 2004. Available at http://wwwgfmerch/ Medical_education_En/PGC_RH_2004/Obstetric_fistula_Kenyahtm accessed Sept 6, 20112004.

37. UNFPA, Health E: Obstetric fistula needs assessment report: Findings from nine African countries. New York: UNFPA; 2003.

38. Prual A, Bouvier-Colle MH, de Bernis L, Breart G: Severe maternal morbidity from direct obstetric causes in West Africa: incidence and case fatality rates. Bull World Health Organ 2000, 78(5):593-602.

39. Higgins JPT, Green S (Eds): Cochrane Handbook for Systematic Reviews of Interventions Version 5.1.0 [updated March 2011]. The Cochrane Collaboration; 2011. Available from www.cochrane-handbook.org.

40. Ronsmans C, Holtz S, Stanton C: Socioeconomic differentials in caesarean rates in developing countries: a retrospective analysis. Lancet 2006, 368(9546):1516-1523.

doi:10.1186/1471-2393-13-246

Cite this article as: Adler et al:: Estimating the prevalence of obstetric fistula: a systematic review and meta-analysis. BMC Pregnancy and Childbirth 2013 13:246.

\section{Submit your next manuscript to BioMed Central and take full advantage of:}

- Convenient online submission

- Thorough peer review

- No space constraints or color figure charges

- Immediate publication on acceptance

- Inclusion in PubMed, CAS, Scopus and Google Scholar

- Research which is freely available for redistribution

Submit your manuscript at www.biomedcentral.com/submit
C Biomed Central 